\title{
Behavior and morphology of Nucella lapillus influenced by predator type and predator diet
}

\author{
Scott I. Large ${ }^{1,2}$, Philip Torres ${ }^{1}$, Delbert L. Smee ${ }^{1, *}$ \\ ${ }^{1}$ Texas A\&M University-Corpus Christi, Corpus Christi, Texas 78412, USA
}

${ }^{2}$ Present address: National Marine Fisheries Service, Northeast Fisheries Science Center, Woods Hole, Massachusetts 02543, USA

\begin{abstract}
To reduce their risk of being eaten, prey may change their morphology or behavior in response to predators, which can result in slower growth and lower fitness. To minimize costs, prey limit anti-predator responses to risky situations, which requires prey to reliably detect cues indicative of predation risk. The purpose of this study was to ascertain how different types of risk cues would affect the multiple responses of a common prey organism. Using the dogwhelk Nucella lapillus as a model, we compared behavioral and morphological responses of dogwhelks to green crabs Carcinus maenas and rock crabs Cancer irroratus when fed diets of conspecific dogwhelks or of marsh periwinkles Littorina littorea, a heterospecific grazing snail. We noted a significant reduction in dogwhelk movement in the presence of both predators, with green crabs causing a significantly greater reduction in movement than rock crabs. Dogwhelks were then exposed to cues from crabs maintained on diets of either dogwhelks or periwinkles continuously for $45 \mathrm{~d}$, and we measured changes in dogwhelk foraging rates on mussels (Mytilus edulis) weekly during the $45 \mathrm{~d}$ exposure, as well as dogwhelk growth. Predator cues suppressed dogwhelk foraging, but regardless of predator type, dogwhelks consumed fewer mussels when predators were eating dogwhelks. Dogwhelks grew significantly less when exposed to crabs consuming injured conspecifics, but growth was unaffected by predators when they were fed periwinkles during induction treatments. These results indicate that cues from both predators and injured conspecifics are used by dogwhelks to evaluate predation risk and that the injured conspecific cue in combination with that of a potential predator causes a greater response than does that of the predator alone. It is necessary to assess multiple types of risk cues and prey responses when studying nonlethal effects predators have on prey because the type and magnitude of prey responses can vary with the type of risk cues detected.
\end{abstract}

KEY WORDS: Chemical cue $\cdot \mathrm{Crab} \cdot \mathrm{Diet} \cdot$ Predator avoidance $\cdot$ Predator-prey interaction Risk assessment

Resale or republication not permitted without written consent of the publisher

\section{INTRODUCTION}

To minimize predation risk, prey use multiple strategies, such as decreasing activity (Vadas et al. 1994, Large \& Smee 2010), reducing foraging behavior (Appleton \& Palmer 1988, Aschaffenburg 2008, Freeman \& Hamer 2009), altering habitat selection (Turner \& Mittelbach 1990), inducing higher levels of chemical defenses (Baldwin 1998, Hay 2009) or developing a more predator-resistant morphology (Ver- meij 1982, Appleton \& Palmer 1988, Palmer 1990, Relyea \& Werner 2000, Relyea 2001a,b). These strategies are costly, often reducing prey growth, fitness, and/or competitive ability (Kats \& Dill 1998, Nakaoka 2000, Relyea \& Werner 2000, Relyea 2001a,b). Prey may use plastic responses to predators to limit costly avoidance strategies in situations where predators pose significant risk of injury or death. In some situations, changes in morphology may result solely from changes in behavior (e.g. reduced foraging) 
and not as a direct response to predators (Bourdeau 2009).

For plastic responses to be effective, prey must reliably detect and respond to predator risk cues. In aquatic environments, prey frequently use chemical cues for this purpose (reviewed by Chivers \& Smith 1998, Ferrari et al. 2010), perhaps because chemical cues provide the most reliable indication of predator presence. Predators may be able to reduce activity and hide or disguise visual or mechanical signals, and may restrict their own emission of dissolved compounds through morphological or behavioral adaptation, but it is unlikely that they are able to completely avoid releasing metabolites through waste products or body secretions (Brown et al. 2000). Moreover, chemical signals include variation in both chemical components and ratios, making a virtually infinite number of distinct signals that prey may use to detect predatory threats (Buck 1996).

Chemical risk cues emanate from predators as well as injured conspecifics and heterospecifics (Chivers \& Smith 1998, Kats \& Dill 1998, Relyea 2001a, Turner 2008). Prey responses to these cues may depend on factors such as time of day (Peckarsky 1996), prey physiological state (Lima \& Dill 1990), or predator diet (Brown \& Dreier 2002, Madison et al. 2002). Prey from populations that experience greater predation pressure may be more likely to detect and react to predation risk and display different types of predator avoidance strategies (Smee \& Weissburg 2008, Edgell 2010).

Since prey may react differently to different risk cues in different situations, measuring one type of prey response to single cues may not adequately quantify how prey evaluate and respond to risk. For example, in short-term behavioral assays, Large \& Smee (2010) found that dogwhelks Nucella lapillus reacted strongly to green crabs Carcinus maenas by reducing their activity level and remaining in refuges, but did not respond to sympatric rock crabs Cancer irroratus or Jonah crabs Cancer borealis. In contrast, Freeman \& Hamer (2009) found that dogwhelks responded to Jonah crabs more than to green crabs. However, Freeman \& Hamer (2009) measured consumption of mussels by dogwhelks while Large \& Smee (2010) measured dogwhelk activity during short-term assays. Further, Palmer (1990) noted that dogwhelks developed more predator-resistant shell morphology in response to the edible crab Cancer pagurus, a result dependent upon dogwhelk habitat and the diet of C. pagurus. Different conclusions drawn by these studies may have resulted from the specific anti-predatory response measured and types of chemical cues presented to prey.

To more completely address how anti-predator responses are influenced by the type of risk cues, we elected to use multiple predators feeding on 2 prey types and measure multiple types of prey reactions to predators, including changes in activity, foraging rates, and morphology. We used a rocky intertidal system consisting of the carnivorous dogwhelk as a model prey, and green crabs and rock crabs, both of which are common dogwhelk predators. Our goal was to determine how chemical cues emanating from these predators actively foraging on either dogwhelks or a sympatric periwinkle Littorina littorea would affect dogwhelk responses to predation risk.

We used dogwhelks as our model organism because they react behaviorally and morphologically to predators, are preyed upon by different crab species, and are known to respond to chemical cues of predators and injured conspecifics (Large \& Smee 2010). Dogwhelks are direct-developing snails and are common on rocky intertidal shorelines along the northwestern Atlantic from Long Island to Greenland. Nucella spp. respond to predation risk by: decreasing their activity and remaining in refuges (Vadas et al. 1994, Large \& Smee 2010), reducing their foraging rate (Burrows \& Hughes 1991, Vadas et al. 1994, Aschaffenburg 2008), and changing their morphology (Appleton \& Palmer 1988, Palmer 1990, Bourdeau 2009). Our results suggest that dogwhelks can discriminate between predators and react differently to them and that dogwhelk foraging and growth rates are more affecting by chemical cues from injured conspecifics than from those emanating from predators alone.

\section{MATERIALS AND METHODS}

\section{General protocol}

To examine how prey respond to predators based upon their diet, we measured initial behavioral response (i.e. activity level) to sympatric predators shortly after collection, and then assessed changes in dogwhelk activity level, consumption of mussels, and the change of dogwhelk morphology after $45 \mathrm{~d}$ of continuous exposure to predators consuming conspecific prey (i.e. dogwhelks) or heterospecific prey. We used the grazing periwinkle snail Littorina littorea as heterospecific prey because these snails are often found alongside dogwhelks. 


\section{Animal collection and care}

Approximately 90 dogwhelks of similar size (shell length $13.56 \pm 0.08 \mathrm{~mm}$, mean $\pm \mathrm{SE}$ ) were collected from 4 rocky intertidal shorelines and immediately transferred to flowing seawater tanks at the Darling Marine Center (DMC) in Walpole, Maine (Table 1). Collections were made over an area of $\sim 200 \mathrm{~m}^{2}$ at each site. In the lab, dogwhelks were maintained in flow-through tanks and fed an ad libitum diet of mussels. Male green and rock crabs with carapace widths $75 \pm 4.0$ and $78 \pm 3.6 \mathrm{~mm}$, respectively, were captured from the Damariscotta River using recreational crab traps. Crabs were immediately transferred to flowing seawater tanks at the DMC and maintained on an ad libitum diet of dogwhelks, periwinkles, and mussels until used in behavioral assays or placement into an induction chamber, where their diets were changed to consist of dogwhelks or periwinkles only (see below). During the experiment, water temperatures ranged from 12 to $16^{\circ} \mathrm{C}$ and salinity remained at $\sim 32$ in all the seawater tanks. After collection, each snail was allowed a $24 \mathrm{~h}$ acclimation period before behavior was observed.

\section{Behavioral assay to measure activity}

Behavioral assays were conducted in a flowthrough laboratory flume $(2.2 \mathrm{~m}$ long $\times 0.53 \mathrm{~m}$ wide $\times$ $0.1 \mathrm{~m}$ deep) at the DMC (for a description of flume see Smee \& Weissburg 2008). Ceramic tiles were used as the substrate and flow velocity remained at $\sim 4 \mathrm{~cm} \mathrm{~s}^{-1}$ for all behavioral assays (see Large et al. 2011), which is within the range of flow velocities experienced by dogwhelks in the field (Leonard et al. 1998, Robinson et al. 2011).

To examine how prey responded to predation risk, dogwhelks were exposed to chemical cues from green and rock crab predators maintained on mixed diets of

Table 1. GPS coordinates of sites in Maine, USA where dogwhelks were collected for this study during 2010

\begin{tabular}{|lcc|}
\hline Site description & Latitude $\left({ }^{\circ} \mathrm{N}\right)$ & Longitude $\left({ }^{\circ} \mathrm{W}\right)$ \\
\hline $\begin{array}{l}\text { Pemaquid Point, } \\
\text { South Bristol }\end{array}$ & 43.83696 & 69.50804 \\
$\begin{array}{l}\text { Long Cove Point, } \\
\text { Chamberlain }\end{array}$ & 43.88519 & 69.47394 \\
$\begin{array}{l}\text { Lower Narrows (East), } \\
\quad \text { Walpole }\end{array}$ & 43.89138 & 69.58330 \\
$\begin{array}{l}\text { Lower Narrows (West), } \\
\text { Boothbay }\end{array}$ & 43.89444 & 69.57699 \\
\hline
\end{tabular}

mussels, dogwhelks, and periwinkles. As both green and rock crabs are generalist predators, mixed diets were appropriate to use for initially measuring dogwhelk responses to these consumers. Previously in short-term behavioral assays, there were no differences in dogwhelk responses to green crabs that had been maintained on mussels versus dogwhelks (Large \& Smee 2010). In the presence of predator cues, dogwhelks seek refuge and decrease their activity (Vadas et al. 1994), and dogwhelk movement was used as a proxy for response to predation risk. To begin each assay, 3 dogwhelks were placed within a crevice between the ceramic tiles that served as a predation refuge (sensu Large \& Smee 2010). Groups of 3 dogwhelks were used because they are typically in groups in the field and previous empirical data had shown that responses to predators are not statistically different when assayed individually or in groups (Large \& Smee 2010). Dogwhelks were started within a refuge because if they were placed away from a refuge on the bare substrate, any subsequent movements could either be (1) failure to respond to predator risk or (2) an active search for refuge in response to predation risk. Dogwhelks were allowed to acclimate for $5 \mathrm{~min}$ before one of 2 predator treatments or a control were introduced $0.5 \mathrm{~m}$ upstream: (1) green crab, (2) rock crab, or (3) no-predator control. Predators were tethered to a ceramic tile, preventing them from moving throughout the flume, but still allowing dogwhelks to be exposed to chemical cues from predators. After the acclimation period, dogwhelk movement was monitored for $20 \mathrm{~s}$ every $5 \mathrm{~min}$ for $30 \mathrm{~min}$, so that dogwhelks were observed 7 times (see Large \& Smee 2010). All movements such as climbing from the refuge, lifting or rotating their shells, or crawling within the refuge were scored equally, and the number of observations of movement was used as our metric for dogwhelk response to predators.

\section{Inducing anti-predatory defenses}

Dogwhelks were exposed to predator cues in chambers consisting of a large plastic aquarium $(60.45 \times$ $39.63 \times 22.61 \mathrm{~cm}$ ) with a perforated barrier bisecting the tank. Seawater was pumped from the Damariscotta River into a header tank, from where it was drained into each aquarium and drained out from the opposite end, creating a gentle current $\left(\sim 2.0 \mathrm{l} \mathrm{min}^{-1}\right.$, current velocity $\sim 0.5 \mathrm{~cm} \mathrm{~s}^{-1}$ ). Within each large aquarium, 2 small, mesh-sided containers $(25.4 \times 17.78 \times$ $10.16 \mathrm{~cm}, 1.50 \mathrm{~mm}$ vexar meshing) were placed downstream of the perforated barrier. The mesh per- 
mitted water to pass through the container containing dogwhelks. Within each mesh-sided container, 15 dogwhelks were placed, along with mussels of 3 size classes: small (shell length 13-17.5 mm), medium $(17.5-20 \mathrm{~mm})$, and large $(20-23.5 \mathrm{~mm})$. For each mesh-sided container, 15 small, 6 medium, and 4 large mussels were included as food for the dogwhelks (Freeman \& Hamer 2009).

Upstream of the perforated barrier bisecting the tank, a control lacking predators or one of 4 predator treatments was placed: (1) green crab fed with dogwhelks, (2) green crab fed with periwinkles, (3) rock crab fed with dogwhelks, or (4) rock crab fed with periwinkles. Dogwhelks and periwinkles used for predator food were $\sim 25 \mathrm{~mm}$ shell length and were collected from rocky shorelines near the DMC. This experiment lasted $45 \mathrm{~d}$ because previous studies demonstrated that this time period was sufficient to observe differences in anti-predatory morphological responses (Trussell \& Smith 2000). Predators were fed 3 to 5 snails every other day, and to facilitate crab feeding snail shells were carefully cracked and placed near each crab. Each experimental chamber contained one predator upstream of 2 containers, each containing 15 snails, and the order of treatments was interspersed between tanks. Deceased crabs were immediately replaced with conspecifics maintained on the same diet. Each predator and diet combination was simultaneously replicated 8 times.

\section{Foraging}

Dogwhelk food supply was replaced weekly with 25 living mussels (15 small, 6 medium, and 4 large), and drilled mussel valves were counted to measure consumption rate. All mussel sizes were readily consumed by dogwhelks. Some dogwhelks perished during the experiment and these individuals were subsequently removed. Mortality was similar among populations and predator induction treatments. Because some dogwhelks perished during the experiment, we standardized consumption rates by dividing the number of mussels consumed by the number of living dogwhelks for data analysis.

\section{Change in shell morphology}

To determine how dogwhelks alter shell morphology in response to different predators fed different diets, shell mass and body mass were predicted using a non-destructive technique (see Palmer 1982 for a detailed description of process). After the initial behavioral assay, apiary tags were attached to each dogwhelk with cyanoacrylate adhesive to uniquely identify them. Then, prior to induction, each dogwhelk was weighed submerged in seawater using an Ohaus SP602 balance readable to $0.01 \mathrm{~g}$. Each snail was then allowed to dry for $30 \mathrm{~m}$ and coaxed back into its shell with an absorbent tissue to collect any residual water and then re-weighed dry. Shell mass was predicted from submerged mass using regressions from a destructive sampling of dogwhelks from all populations (Palmer 1982). As with other experiments utilizing this method (Burrows \& Hughes 1991, Freeman \& Hamer 2009), regression curves were highly significant $\left(\mathrm{R}^{2}>0.99\right)$. Upon completion of the $45 \mathrm{~d}$ induction period, each snail was re-weighed to compare the change in body and shell mass between predator treatments, predator diets, and habitats.

\section{Statistical analysis: behavioral assay to measure activity}

The number of dogwhelk movements in the presence of green crabs, rock crabs, and controls was analyzed using a 1-way ANOVA with predator (green crab, rock crab, and no-predator control) as the main effect. Pair-wise differences were compared using Tukey-Kramer post hoc tests.

\section{Statistical analysis: foraging}

The design of this experiment was not balanced because diet treatments were not applied to the nopredator controls. Therefore, we did not include controls in the foraging analysis. The number of mussels consumed was compared using a 2-factor, repeatedmeasures ANOVA with predator type and predator diet as main, fixed effects and week as the repeated measure. All tests met the assumptions of ANOVA (Sokal \& Rohlf 1995). Repeated-measures analysis was tested for violation of sphericity using Mauchly's $W$-test in the 'ez' package (Lawrence 2010) of $\mathrm{R}$ (R Development Core Team 2010).

\section{Statistical analysis: change in shell morphology}

To compare how morphological measures were influenced by long-term exposure to predation risk, final body mass and shell mass were subtracted from initial body mass and shell mass. This standardized 
differences present in initial snail size. For both shell mass and body mass, a 2-factor ANOVA was used, with predator type and predator diet as main, fixed effects and aquarium as a random effects factor within the 2-way interaction of predator-diethabitat in the ANOVA model (Sokal \& Rohlf 1995). As with the foraging analysis, controls were excluded from the 2-way ANOVA. In comparing induced behavioral response and morphology the number of replicates was not equal among treatments and Type III sum of squares were used to properly calculate the F-ratios (Sokal \& Rohlf 1995).

\section{RESULTS}

\section{Behavioral response to predation risk: activity}

Dogwhelks movements were compared when in the presence of green crabs, rock crabs, and nopredator controls. We found a significant reduction in movement in the presence of both crabs as compared to control treatments $\left(F_{2,255}=93.8, \mathrm{p}<0.001\right.$, Fig. 1$)$. Post hoc analysis indicated that green crabs caused a significantly greater reduction in movement than did rock crabs, although both predator treatments were significantly different from the controls (Fig. 1).

\section{Foraging}

Our data did not violate sphericity (Mauchly's $W=$ $0.51, p=0.17$ ), permitting use of a 2 -factor repeatedmeasure ANOVA. We found significant effects of predator type $\left(F_{1,28}=8.26, \mathrm{p}<\right.$ $0.01)$ and predator diet $\left(F_{1,28}=43.3, \mathrm{p}<\right.$ 0.001 ) on the foraging rates of dogwhelks on mussels (Fig. 2), but did not find a significant interaction between these factors $\left(F_{1,28}=0.01, \mathrm{p}=0.98\right)$. Dogwhelks foraged less frequently in the presence of green crabs than rock crabs and reduced foraging more when predators were eating other dogwhelks. The repeated-measure week was also significant $\left(F_{5,24}=12.45, \mathrm{p}<\right.$ 0.001) as dogwhelks reduced foraging rates during the $45 \mathrm{~d}$ experiment. Interactions between week and predator type $\left(F_{5,24}=0.72, \mathrm{p}=0.61\right)$, week and predator diet $\left(F_{5,24}=2.57, \mathrm{p}=0.054\right)$, and the 3-way interaction between all factors $\left(F_{5,24}=1.30, \mathrm{p}=0.61\right)$ were not

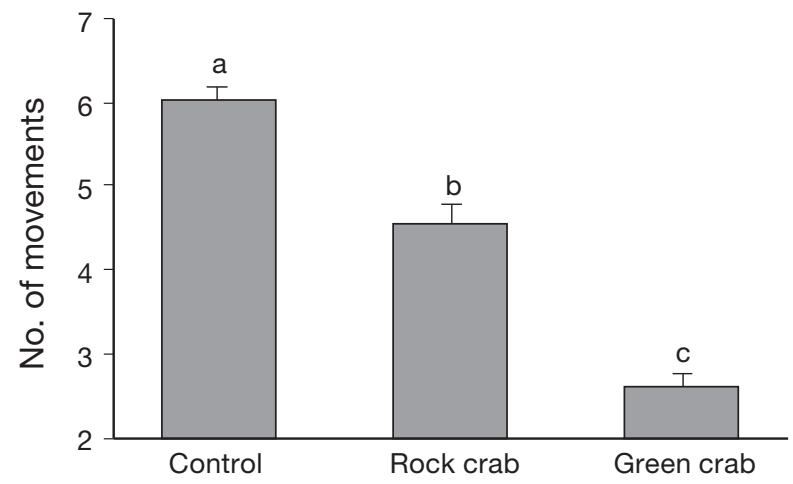

Fig. 1. Mean $( \pm \mathrm{SE})$ number of movements of dogwhelks in response to green and rock crab predator cues and nopredator controls. Significant differences among treatments were found with ANOVA ( $p<0.001)$, and letters denote pair-wise differences based upon a Tukey-Kramer post hoc test

significant. The week $\times$ predator diet interaction was almost significant, and we noted that the decline in dogwhelk consumption of mussels was more pronounced in treatments when predators were eating dogwhelks.

\section{Morphological response to predation risk}

Shell mass and body mass differed significantly between treatments after a 45 d exposure to exudates from actively foraging predators. Predator diet significantly affected dogwhelk growth as the crab-fedwith-dogwhelk treatment resulted in significantly less

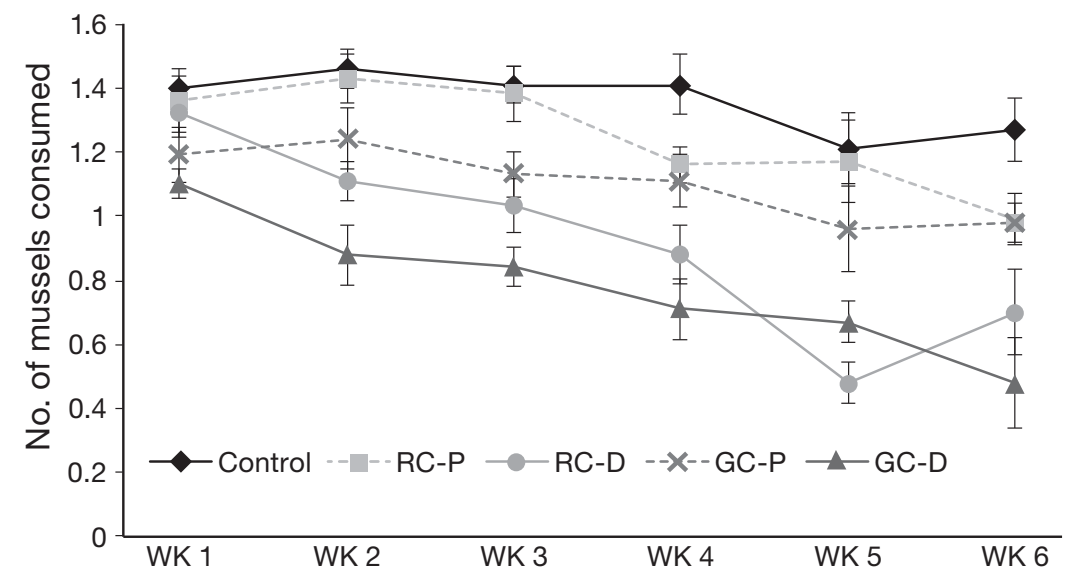

Fig. 2. Mussels consumed per dogwhelk (mean $\pm \mathrm{SE}$ ) in response to chemical exudates from green (GC) and rock (RC) crabs maintained on a diet of periwinkles (P) and dogwhelks (D), measured weekly over a $45 \mathrm{~d}$ induction period $(\mathrm{n}=8)$. Dogwhelk foraging rates were significantly affected by both predator type and predator diet, with the strongest foraging reduction observed when predators were consuming conspecific dogwhelks $(\mathrm{p}<0.001)$ 
shell mass $(p<0.001)$ and body mass $(p<0.001)$ than the crab-fed-with-periwinkle treatment (Fig 3, Table 2). Predator type did not affect snail growth as no significant differences in growth were noted in either shell mass $(p=0.54)$ or body mass $(p=0.30)$ between green and rock crab treatments (Fig 3, Table 2). The interaction term between predator diet and predator type was not significant for shell or body growth (Table 2 ).

\section{DISCUSSION}

To determine how prey respond to differing levels of predation risk, many studies have exposed prey to a variety of chemical cues such as conspecific alarm cue, injured con- or heterospecifics, predators, different predators fed different diets, and combinations of these risk cues (Chivers \& Smith 1998, Kats \& Dill 1998, Ferrari et al. 2010). While all of these cues can be indicative of risk, prey responses to each may be highly context dependent. In some instances, prey show sensitivity to variation in predator diet (Palmer 1990, Chivers et al. 1996, Relyea \& Werner 2000, Turner 2008), while in other cases they do not (Bryer
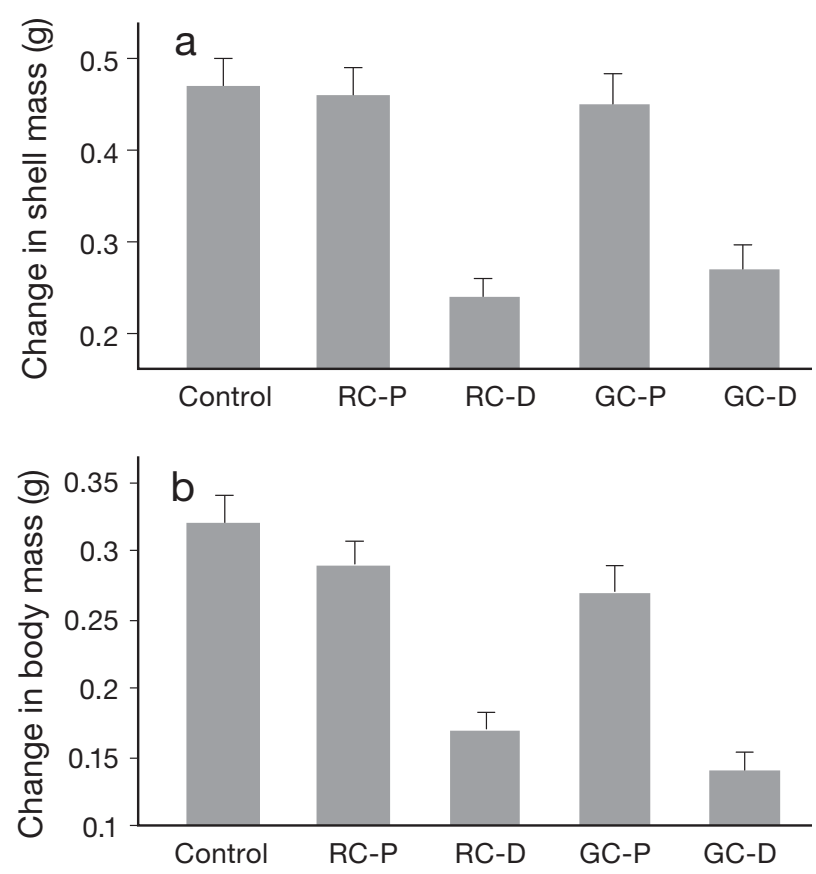

Fig. 3. Change (mean $+\mathrm{SE}$ ) in dogwhelk (A) shell mass and (B) body mass over a $45 \mathrm{~d}$ induction period in response to green (GC) and rock (RC) crabs maintained on diets of periwinkles (P) and dogwhelks (D). Dogwhelk body and shell growth was significantly reduced when predators were consuming dogwhelks $(\mathrm{p}<0.001)$ but was not significantly different between different predator species $(p>0.3)$
Table 2. Results of ANOVA of changes in shell mass and body mass in response to different experimental treatments. Dogwhelk growth was significantly reduced in treatments in which predators were consuming dogwhelks

\begin{tabular}{|lcccc|}
\hline Source & SS & df & $F$ & $p$ \\
\hline Shell Mass Changes & & & & \\
Predator & 0.02 & 1 & 0.21 & 0.65 \\
Diet & 3.28 & 1 & 57.69 & $<0.001$ \\
Predator $\times$ Diet & 0.01 & 1 & 0.21 & 0.64 \\
Aquarium (Predator $\times$ & 0.69 & 28 & 0.09 & 0.35 \\
$\quad$ Diet) Random & & & & \\
Body Mass Changes & & & & \\
Predator & 0.02 & 1 & 0.98 & 0.33 \\
Diet & 1.43 & 1 & 31 & $<0.001$ \\
Predator $\times$ Diet & 0.01 & 1 & 0.03 & 0.86 \\
Aquarium (Predator $\times$ & 3.01 & 28 & 0.83 & 0.70 \\
$\quad$ Diet) Random & & & & \\
\hline
\end{tabular}

et al. 2001, Smee \& Weissburg 2006, Large \& Smee 2010); or they may express different types of responses to different predators (Freeman \& Hamer 2009). To assess how different types of cues affect different types of prey responses, we measured several prey responses when presented with risk cues from predators foraging on conspecific dogwhelks or sympatric but unrelated periwinkles.

Predator-induced defenses can mirror the dangerousness of predators (Bourdeau 2009, Hettyey et al. 2011), and in this study green crabs likely pose the largest threat to dogwhelks since both green crabs and dogwhelks inhabit the intertidal zone, whereas rock crabs are primarily subtidal (Donahue et al. 2009). Green crabs caused a significantly greater suppression of dogwhelk movement than did rock crabs (Fig. 1). Dogwhelk foraging was significantly reduced when dogwhelks were being consumed regardless of the predator species, indicating that the conspecific cues in conjunction with predator cues suppress dogwhelk foraging more than do cues from predators alone (Fig. 2). This is consistent with earlier studies showing that dogwhelks reduced movement in the presence of injured conspecific cues but not to those of other injured sympatric prey species including blue mussels and periwinkles (Large \& Smee 2010).

Similarly, dogwhelks grew less body and shell mass when predators were consuming dogwhelks (Figs. 2 \& 3). However, there was no significant effect of predator species on dogwhelk growth, unlike the results from behavioral assays measuring dogwhelk movements and foraging. This suggests that predator diet, specifically a chemical cue from conspecifics being eaten, causes a significant reduction in dog- 
whelk foraging as well as their overall growth and fecundity. A lighter shell resulting from responding to predators may increase dogwhelk vulnerability to predators. Our results show that different types of prey responses can be affected by different types of predator cues. Specifically, cues from predators eating dogwhelks affected the growth of other dogwhelks while the presence of predators eating periwinkles did not, although both predators and injured conspecifics affect dogwhelk activity level and foraging rates. Careful consideration of the cues prey receive and the metrics used to quantify prey responses are warranted to better develop predictive models of non-lethal predator effects in food webs.

Some prey species limit reactions to predators only when predators have recently eaten conspecifics (Chivers et al. 1996). These situations occur when predator diet can reliably indicate predator risk, such as when predators switch between prey seasonally (Chivers \& Mirza 2001). Large \& Smee (2010) found that in short-term behavioral assays dogwhelks did not respond differently to green crabs fed diets of dogwhelks versus mussels. In the absence of predator cues, crushed dogwhelks elicited a strong antipredatory behavioral response, but crushed periwinkles and mussels did not (Large \& Smee 2010). Since both rock and green crabs reduced dogwhelk foraging behavior (Fig. 2) and injured conspecifics can limit activity (Large \& Smee 2010), the experimental dogwhelks were receiving cues both from predators and injured conspecifics simultaneously in treatments in which green crabs were eating dogwhelks. The combined cues may have introduced a synergistic cue larger than green crab or crushed conspecifics separately (Bourdeau 2009, Ferrari et al. 2010). Future research should explore the separate and combined influence of these cues on dogwhelk anti-predatory behavior and morphology (but see Bourdeau 2009).

Numerous studies during the past 2 decades have shown predators to exert significant effects on prey populations and entire communities through nonconsumptive mechanisms such as reducing the foraging rates of prey (Palmer 1990, Freeman \& Hamer 2009). Recent reviews suggest that non-lethal predator effects exert equal or larger effects than those of direct consumption (Preisser et al. 2005, 2007). For non-lethal predator effects to occur, prey must detect and respond to cues emanating from predators or other indicators of predation risk (e.g. injured conspecifics). Changes in the type or nature of cues can affect the occurrence and magnitude of non-lethal predator effects (Schoeppner \& Reylea 2005, Turner
2008, Large \& Smee 2010). As shown in the present study, non-lethal predator effects can vary depending upon the type and quantity of risk cues, as well as the metric used to quantify non-lethal predator effects (i.e. changes in activity, foraging, and morphology).

Aspects such as predator diet and the relative risk a predator poses can influence multiple aspects of prey behavior and morphology. Additionally, each of these factors does not act independently, and measuring a single factor or a single response might misrepresent if, and to what degree, prey react to predators after detection of chemical cues indicative of risk. Measuring non-lethal predator effects in nature is important, but may be affected by many factors including ambient predation pressure in populations of study animals, quality and quantity of cue source, cue delivery, and the type of prey response(s) measured (Schoeppner \& Relyea 2005, Turner 2008, Ferner et al. 2009, Freeman \& Hamer 2009). Future studies that seek to understand and predict the occurrence and magnitude of non-lethal predator effects in nature should empirically test these factors.

Acknowledgements. We thank P. Jumars for allowing the use of his flume for the behavioral experiments, T. Miller for logistical support at the DMC, and for all other DMC personnel that assisted throughout the study. I. Philbrook assisted in measuring hundreds of snails. We also thank TAMU-CC Marine Ecology Lab, especially E. Robinson, for help with animal care and tank maintenance. Comments from 3 anonymous reviewers significantly improved earlier drafts of the manuscript. Funding support for this project came from NSF-OCE grant 0648433 and from the Texas Research Development Fund to D.L.S. and from the Addison E. Verrill Award for Marine Biology to S.I.L.

\section{LITERATURE CITED}

Appleton RD, Palmer AR (1988) Water-borne stimuli released by predatory crabs and damaged prey induce more predator-resistant shells in a marine gastropod. Proc Natl Acad Sci USA 85:4387-4391

- Aschaffenburg M (2008) Different crab species influence feeding of the snail Nucella lapillus through trait-mediated indirect interactions. PSZNI: Mar Ecol 29:348-353

Baldwin IT (1998) Jasmonate-induced responses are costly but benefit plants under attack in native populations. Proc Natl Acad Sci USA 95:8113-8118

> Bourdeau PE (2009) Prioritized phenotypic responses to combined predators in a marine snail. Ecology 90: 1659-1669

Brown GE, Dreier VM (2002) Predator inspection and attack cone avoidance in the characin fish: the effects of predator diet and prey experience. Anim Behav 63:1175-1181

Brown GE, Paige JA, Godin JGJ (2000) Chemically mediated predator inspection behaviour in the absence of predator visual cues by a characin fish. Anim Behav 60: 315-321 
Bryer PJ, Mirza RS, Chivers DP (2001) Chemosensory assessment of predation risk by slimy sculpins (Cottus cognatus): responses to alarm, disturbance, and predator cues. J Chem Ecol 27:533-546

$>$ Buck LB (1996) Information coding in the vertebrate olfactory system. Annu Rev Neurosci 19:517-544

> Burrows M, Hughes R (1991) Optimal foraging decisions by dogwhelks, Nucella lapillus (L.): influences of mortality risk and rate-constrained digestion. Funct Ecol 5461-475

> Chivers DP, Mirza RS (2001) Importance of predator diet cues in responses of larval wood frogs to fish and invertebrate predators. J Chem Ecol 27:45-51

Chivers DP, Smith RJF (1998) Chemical alarm signaling in aquatic predator-prey systems: a review and prospectus. Ecoscience 5:338-352

> Chivers DP, Wisenden BD, Smith RJF (1996) Damselfly larvae learn to recognize predators from chemical cues in the predator's diet. Anim Behav 52:315-320

> Donahue M, Nichols A, Santamaria C, League-Pike P, Krediet C, Perez K, Shulman M (2009) Predation risk, prey abundance, and the vertical distribution of three brachyuran crabs on Gulf of Maine shores. J Crustac Biol 29: 523-531

Edgell TC (2010) Past predation risk induces an intertidal whelk (Nucella lamellosa) to respond to more dilute concentrations of its predator's scent. Mar Biol 157:215-219

Ferner MC, Smee DL, Weissburg MJ (2009) Habitat complexity alters lethal and non lethal olfactory interactions between predators and prey. Mar Ecol Prog Ser 374: 13-22

Ferrari MCO, Wisenden BD, Chivers DP (2010) Chemical ecology of predator-prey interactions in aquatic ecosystems: a review and prospectus. Can J Zool 88:698-724

Freeman A, Hamer C (2009) The persistent effect of wave exposure on TMIIs and crab predation in Nucella lapillus. J Exp Mar Biol Ecol 372:58-63

Hay ME (2009) Marine chemical ecology: chemical signals and cues structure marine populations, communities, and ecosystems. Annu Rev Mar Sci 1:193-212

> Hettyey A, Vincze K, Zsarnóczai S, Hoi H, Laurila A (2011) Costs and benefits of defences induced by predators differing in dangerousness. J Evol Biol 24:1007-1019

Kats LB, Dill LM (1998) The scent of death: chemosensory assessment of predation risk by animals. Ecoscience 5: 361-394

> Large SI, Smee DL (2010) Type and nature of cues used by Nucella lapillus to evaluate predation risk. J Exp Mar Biol Ecol 396:10-17

Large SI, Smee DL, Trussell GC (2011) Environmental conditions influence the frequency of prey responses to predation risk. Mar Ecol Prog Ser 422:41-49

Lawrence M (2010) Package 'ez': easy analysis and visualization of factorial experiments, version 2.1-0. R Foundation for Statistical Computing, Vienna

> Leonard GH, Levine JM, Schmidt PR, Bertness MD (1998) Flow-driven variation in intertidal community structure in a Maine estuary. Ecology 79:1395-1411

Lima SL, Dill LM (1990) Behavioral decisions made under the risk of predation-a review and prospectus. Can J Zool 68:619-640

> Madison DM, Sullivan AM, Maerz JC, McDarby JH, Rohr JR (2002) A complex, cross-taxon, chemical releaser of antipredator behavior in amphibians. J Chem Ecol 28:2271-2282

Editorial responsibility: Christine Paetzold, Oldendorf/Luhe, Germany
Nakaoka M (2000) Nonlethal effects of predators on prey populations: predator-mediated change in bivalve growth. Ecology 81:1031-1045

Palmer A (1982) Growth in marine gastropods: a nondestructive technique for independently measuring shell and body weight. Malacologia 23:63-74

Palmer A (1990) Effect of crab effluent and scent of damaged conspecifics on feeding, growth, and shell morphology of the Atlantic dogwhelk Nucella lapillus (L.). Hydrobiologia 193:155-182

Peckarsky BL (1996) Alternative predator avoidance syndromes in stream-dwelling mayflies. Ecology 77 : 1888-1905

Preisser EL, Bolnick DI, Benard MF (2005) Scared to death? The effects of intimidation and consumption in predatorprey interactions. Ecology 86:501-509

Preisser EL, Orrock JL, Schmitz OJ (2007) Predator hunting mode and habitat domain alter nonconsumptive effects in predator-prey interactions. Ecology 88:2744-2751

R Development Core Team (2010) R: a language and environment for statistical computing. R Foundation for Statistical Computing, Vienna

> Relyea R (2001a) The relationship between predation risk and antipredator responses in larval anurans. Ecology 82:541-554

Relyea RA (2001b) Morphological and behavioral plasticity of larval anurans in response to different predators. Ecology 82:523-540

Relyea RA, Werner EE (2000) Morphological plasticity in four larval anurans distributed along an environmental gradient. Copeia 2000:178-190

Robinson EM, Smee DL, Trussell GC (2011) Green crab (Carcinus maenas) foraging efficiency reduced by fast flows. PLoS ONE 6:e21025

Schoeppner NM, Relyea RA (2005) Damage, digestion, and defense: the roles of alarm cues and kairomones for inducing prey defenses. Ecol Lett 8:505-512

Smee DL, Weissburg MJ (2006) Hard clams (Mercenaria mercenaria) evaluate predation risk using chemical signals from predators and injured conspecifics. J Chem Ecol 32:605-619

> Smee DL, Weissburg MJ (2008) Heightened prey responses in risky habitats: predation pressure increases prey sensitivity to predation risk. Mar Ecol Prog Ser 363:39-50

Sokal RR, Rohlf FJ (1995) Biometry: the principles and practice of statistics in biological research. WH Freeman, New York, NY

> Trussell GC, Smith LD (2000) Induced defenses in response to an invading crab predator: an explanation of historical and geographic phenotypic change. Proc Natl Acad Sci USA 97:2123-2127

Turner A (2008) Predator diet and prey behaviour: freshwater snails discriminate among closely related prey in a predator's diet. Anim Behav 76:1211-1217

Turner A, Mittelbach G (1990) Predator avoidance and community structure: interactions among piscivores, planktivores, and plankton. Ecology 71:2241-2254

Vadas R, Burrows M, Hughes R (1994) Foraging strategies of dogwhelks, Nucella lapillus (L.): interacting effects of age, diet and chemical cues to the threat of predation. Oecologia 100:439-450

Vermeij G (1982) Phenotypic evolution in a poorly dispersing snail after arrival of a predator. Nature 299:349-350

Submitted: October 12, 2011; Accepted: June 4, 2012

Proofs received from author(s): July 30, 2012 